\title{
PARTISIPASI STAKEHOLDERS ISLAM DALAM UPAYA MEREFORMASI PERATURAN DAERAH TENTANG USAHA TEMPAT HIBURAN DI KOTA PROBOLINGGO
}

\author{
Imam Sucahyo \\ Fakultas Ilmu Sosial dan Ilmu Politik - Universitas Panca Marga, Probolinggo \\ Email: imamsucahyo80@gmail.com
}

\begin{abstract}
The nightlife scene is inevitable. Through Perda Kota Probolinggo Number 9 of 2010 it is regulated. However, in its development, it has little impact on society; Covert prostitution, the circulation of liquor, disputes between visitors, and moral decadence, made the Islamic stakeholders critical of guarding the local regulation, until finally the new law was born. This paper seeks to see how the participation of stakeholders labeled Islam ultimately succeeded in reforming this policy. The method in this research is descriptive qualitative with focus on three Islamic stakeholders, which are in the policy arena, outside policy but formal and outside but informal. Data is taken through observation, interview and documentation. Methods of data analysis using interactive analysis model Miles and Huberman. The results concluded; 1) Partisiapasi of Islamic stakeholders in the policy area conducted by the PKB and PPP factions joined in Commission X. Through the legislative authority of this group proposed Raperda after previously hearing and cooperating with LPPMUB. Supervision authority is carried out by recommendation. 2) The participation of Islamic stakeholders outside the policies incorporated in the main formal organization comes from NU circles. The group is pro actively guarding every phenomenon as a result of the enactment of local regulations, starting letters of recommendation, joining in the hearing, giving moral support to the Police, and so on. 3) The participation of Islamic stakeholders outside the policy sphere and not directly incorporated in formal organizations is used as the last ammunition through demonstration media.
\end{abstract}

Key Word: Stakeholders of Islam, Reform, Policy

\section{PENDAHULUAN}

Kota Probolinggo merupakan kota kecil dengan mayoritas penduduk beragama Islam.Kota ini dikenal sebagai daerah tapal kuda dimana massa penganut Nahdlatul Ulama (NU) berbasis, disamping struktur masyarakatnya yang masih menjunjung tinggi norma, adat-istiadat, budaya ketimuran sekaligus nilai-nilai sosial. Namun seiring perkembangan jaman, modernisasi, globalisasi, dan westernisasi menjadikan Kota Probolinggo dihinggapi oleh hingar bingar dunia hiburan semakin tidak terelakkan, khususnya tempat hiburan karaoke keluarga. Melalui Perda Kota Probolinggo Nomor 9 130 | PUBLISIA (Jurnal Ilmu Administrasi Publik)
Tahun 2010 tentang Ijin Hiburan,tempattempat karaoke "halal" beroperasi hingga larut malam. Sekilas mengenai hiburan karaoke keluarga seolah tidak mengesankan masalah, namun justru di tempat inilah sumber masalah berasal; prostitusi terselubung, beredarnya minuman keras, pertikaian antar pengunjung, hedonisme, hingga dekadensi moral generasi muda yang sistemik dan masif adalah sekelumit contohnya. Disamping itu, implementasi Perda Kota Probolinggo Nomor 9 Tahun 2010 yang tidak sesuai dengan ketentuan menjadikan tempat hiburan senantiasa menjadi sorotan. Ambillah contoh mengenai 
ijin karaoke terhadap "JJ Royal" yang ternyata menyajikan tarian erotis dan disinyalir sebagai distributor minuman keras (miras). Padahal tempat tersebut tidak memiliki ijin untuk kegiatan tarian erotis dan miras. (Radar Bromo, 2 Feberuari 2015) Ini menunjukkan adanya ketidakberesan dalam tataran implementasi, bisa karena tiadanya pengawasan, atau kesengajaaan oknum yang mengambil kesempatan demi keuntungan semata.

Contoh lain adalah, berkenaan dengan pemberian ijin pendirian tempat hiburan di kawasan "terlarang". Dalam pasal 59 ayat 5 huruf d Perda Kota Probolinggo Nomor 2 Tahun 2010 tentang Rencana Tata Ruang Wilayah (RTRW)menetapkan Jalan Mastrip sebagai kawasan pendidikan,namun justru disana terdapat gedung karaoke "Ayang" yang berdiri megah. Tak ayal kondisi demikian membuat protes berdatangan karena masyarakat merasa Pemerintah Kota Probolinggo telah melanggar Perda RTRW. Pun demikian Pemerintah Kota berdalih jika ketentuan tersebut tidak kemudian diartikan pelarangan atas sektor jasa dan perdagangan, masih ada toleransi 10 persen untuk sektor lain. Tak ayal, Anggota Dewan Komisi A pun menyatakan hal tersebut terjadi karenakecacatan produk hukum dan ijin atas tempat hiburan harus di cabut. (Radar Bromo, 26 Maret 2013)

Usaha tempat hiburan harus diakui memberikan pemasukan yang tidak sedikit bagi PAD Kota Probolinggo. Atas penelusuran melalui laman daring, per tahun 2016 silam saja sedikitnya menghasilkan 434 juta lebih. (wartabromo.com) Jumlah tersebut cukup fantastis, mengingat hanya disumbang oleh tiga tempat usaha hiburan yang tersisa, yakni Bee Jay, Pop City, dan 888. Belum lagi pemasukan dari sisi retribusi parkir, pajak minuman beralkohol, dan sebagainya. Inilah sejatinya yang mempertautkan antara kepentingan pemerintah (state)dengan kepentingan swasta (private)sehingga membentuk kekuatan untuk menge-goalkan kebijakan tertentu yang pro investorwalaupun di sisi lain mengorbakan kepentingan civil society. Padahal, hubungan ketiganya dalam konteks good governance menurut Tascereu dan Campos (dalam Thoha, 2003:63) menjamin adanya kesejajaran, kesamaan, kohesi, keseimbangan peran serta dan adanya saling kontrol. Namun, sayangnya, yang terjadi seolah pemerintah lebih condong terhadap pelaku usaha hiburan atau investor (market).

Di sisi lain, kelompok stakeholders Islam Kota Probolinggo melihat ekses atas beroperasinya usaha hiburan ini yang dinilai sudah sangat mengkhawatirkantidaklahtinggal diam. Stakeholder dalam konsep Mitroff (1983) dan Freeman (1984) merupakan individu atau kelompok yang dapat berpengaruh atau dipengaruhi oleh pencapaian tujuan organisasi (dalam Brinkerhoff, 2002:59)bisa berada di dalam dan di luar gelanggang kebijakan. Maka mayoritas penduduk Kota Probolinggo yang beragama Islam dan sebagai basis NU, sangat logis jika kemudian menghasilkan kekuatan stakeholdersyang bernafaskan keIslaman yang cukup besar.Di dalam lini arena kebijakan diantaranya adalah partai politik yang ber-platform Islam, seperti PKB, PPP, PKS, yang sangat nyata memiliki keterwakilan di ranah legislatif daerah.Di luar 
itu ada PC. NU, PC. Al-Irsyad, LDII, LDI, PD Muhammadiyah dan MUI Kota Probolinggo. Bahkan PW. NU pun menaruhperhatian khusus dengan melayangkan surat rekomendasi penutupan tempat hiburan malam kepada Pemerintah Kota Probolinggo dan secara nyata menuding "JJ Royal" dan "Ayang" Karaoke sebagai sumber kemerosotan moral dan berkembangnya kejahatan moral. (Radar Bromo, 5 Mei 2015)Stakeholder Islam lain adalah Forum Komunikasi Ormas Islam Kota Probolinggo, Jaringan Koordinasi Madrasah Aliyah Swasta (Jakmas),kalangan mahasiswa melalui PMII Probolinggo hingga sosok kyai dankekuatan massa santri pondok pesantrennya. Partisipasi mereka sebagai stakeholdersIslam memiliki andil sangat besar untuk merubah atau pun mereformasi kebijakan yang ada(policy change). Dan sebagaimana konsep Worl Bank (1996:3), mendefinisikan partisipasi sebagai proses dimana pengaruh stakeholder dan perimbangan kontrol melalui inisiatif dan keputusan sumberdaya yang berkenaan dengannya. Maka definisi tersebut sangat tepat guna menjelaskan perubahan kebijakan bersamadengan momen-momen implementasi Perda sebelumnya yang dinilai tidak sesuai dengan yang telah digariskan, berikut aksiaksi konkrit lain sehingga upaya-upaya tersebut membuahkan hasil, yakni melalui dikeluarkannya Perda Kota Probolinggo Nomor 9 Tahun 2015 tentang Penataan, Pengawasan, dan Pengendalian Usaha Tempat Hiburan.

Namun, untuk melihat bagaimana senyatanya sepak terjang yang dilakukan oleh para stakeholdersIslam ini dalam mengawal implementasi kebijakan, khususnya Perda tentang usaha hiburan di Kota Probolinggo hingga kemudian terjadi reformasi kebijakan adalah inti bahasan yang hendak penulis kemukakan dengan melihat beberapa konsep yang telah dikemukakan oleh beberapa pakar dalam sub bahasan policy change.Tulisan ini hendak mengetahui sejauh mana partisipasi stakeholdersdapat merubah kebijakan daerah, khususnya yang berkenaan dengan Perda tentang hiburan di Kota Probolinggo tentu mengaitkannya dengan beberapa konsep/teori dalam sub bahasan policy change. Sedangkan manfaatnya semoga dapat memberikan sumbangsih masukan terhadap aktor-aktor lain, baik pemerintah daerah, anggota dewan daerah, masyarakat, danstakeholderssecara umum dalam kepentingannya untuk mereformasi kebijakan tertentu, khususnya di tingkat daerah kabupaten/kota agar lebih mumpuni baik konten ataupun implementasinya. Manfaat lain diharapkan dapat memberikan kontribusi konsep baru atas partisipasi stakeholdersIslam yang telah dilakukan di setting tempat yang juga berpenduduk mayoritas Islam, yakni Kota Probolinggo.

\section{KONSEP PARTISIPASI DAN STAKEHOLDER DALAM UPAYA ME- REFORM KEBIJAKAN}

Berbicara mengenai partisipasi dalam kebijakan publik, tentu tidak akan lepas dari upaya pemerintah khususnya pemerintah daerah dalam menciptakan tata pengelolaan pemerintahan yang baik (Good Governance). Salah satunya adalah terumusnya secara tegas prasyarat partisipasi sebagai bagian dari keseluruhan proses kebijakan, mulai dari tahap kebijakan diformulasikan, 
diimplementasikan dan dievaluasi. Disamping prinsip transparansi dan akuntabilitas. Keterlibatan masyarakat dalam proses kebijakan merupakan bentuk transparansi pemerintah terhadap masyarakat. Transparansi dan akuntabilitas publik adalah salah satu syarat bagi penyelenggaraan pemerintah untuk mewujudkan Good Governance (Hardjasoemantri, 2003). Berarti, partisipasi dalam kebijakan publik tertentu berkolerasi dengan kepentingan publik secara luas yang seharusnya diapresiasi secara proporsional. $\mathrm{Di}$ satu sisi merupakan keniscayaan sebagai tuntutan global, sisi yang lain merupakan akomodasi politik atas kesadaran kritis masyarakat sebagai respon terhadap pelaksanaan demokrasi, pemerintahan, dan kebijakan yang ada.

Hal utama dalam partisipasi adalah, bahwa masyarakat tidak sekedar terlibat atau ikut serta, yang jika ditelusur kemudian bermuara karena paksaan ataupun karena motif tertentu, seperti pemberian imbalan, iming-iming, dan lain-lain. Melainkan sebuah partispasi yang didasarkan atas kesadaran untuk lebih berupaya dalam melakukan perubahan yang mendasar atas sebuah kebijakan, baik di awal (formulasi), di tengah (implementasi) ataupun di akhir (evaluasi). Secara umum partisipasi diartikan prinsip bahwa setiap orang memiliki hak untuk terlibat dalam pengambilan keputusan di setiap kegiatan penyelenggaraan pemerintahan (Ruslan, 2005:193).Bagi Sumanto (2006:127) partisipasi warga dalam governance adalah keterlibatan warga dalam pembuatan keputusan mengenai penggunaan sumberdaya publik dan pemecahan masalah- masalah publik untuk pembangunan daerahnya. Kualitas governance dinilai dari kualitas interaksi yang terjadi antara komponen governance, yaitu pemerintah, sektor swasta, dan kelompok masyarakat.

Jika demikian makamerangkul sebanyak-banyaknya, seluas-luasnya partisipasi masyarakatdengan sendirinya akan menjadikan suatu kebijakan akan diterima oleh masyarakat secara luas dan dalam implementasinya kelak juga tidak akan mengalami hambatan berarti. Hal ini sesuai dengan ungkapan Brinkerhoff dan Crosby (2002:55-56)bahwa perluasan partisipasi akan melahirkan jaminan atau peningkatan keberhasilan implementasi kebijakan dan pemberian pelayanan yang lebih baik; meningkatkan dukungan, legitimasi, transparansi dan responsivitas atas kebijakan tertentu; meningkatkan kemungkinan implementasi atau keberlanjutan sebuah kebijakan. Karenanya partisipasi perlu dikelola dengan baik, terlebih menjadikannya sebagai tradisi dalam setiap proses kebijakan,yang akan memberikan keuntungan tersendiri. Uphoff (1998) mengungkap bahwa tradisi partisipasi akan membentuk modal sosial (social capital), terciptanya kelompok yang lebih mampu mengorganisir diri secara independen, mengartikulasikan tuntutan, bermanuver dengan sukses di berbagai arena kebijakan, dan berinteraksi dengan pejabat publik dengan baik. Semakin banyak kelompok berpengalaman dalam partisipasi, semakin besar kemungkinan mereka mengembangkan pola saling percaya, memobilisasi isu, melakukan tindakan kolektif, dan sukses dalam mengamankan proses kebijakan dan dalam mempengaruhi 
keputusan. (dalam Brinkerhoff dan Crosby, 2002:76)

Lebih jauh, Irvin and Stansbury (2004:55) menyatakan bahwa partisipasi masyarakat dalam pembuatan keputusan akan melahirkan keuntungan dan kelemahan, baik bagi pemerintah ataupun masyarakat itu sendiri. Keuntungan bagi masyarakat diantaranya adalah; adanya pembelajaran, meningkatnya skill masyarakat, memecah kebuntuan dan mencapai hasil, adanya kontrol terhadap proses kebijakan, terciptanya kebijakan dan implementasi kebijakan yang lebih baik, dan sebagainya. Keuntungan bagi pemerintah diantaranya adalah; adanya pembelajaran, membangun kepercayaan dan menenangkan kegelisahan atau permusuhan, membangun aliansi strategis, tercapainya legetimasi keputusan, memecah kebuntuan dan mencapai hasil, terciptanya kebijakan dan implementasi kebijakan yang lebih baik, dan sebagainya. Sedangkan kerugiannya bagi masyarakat adalah; memakan waktu lama bahkan membosankan, tidak bermakna apapun jika hasil keputusan diabaikan, akan menjadi keputusan kebijakan yang buruk jika secara kuat dipengaruhi oleh kelompok kepentingan oposisi. Dan kerugian bagi pemerintah adalah; memakan waktu lama, berbiaya mahal, bisa menjadi bumerang dan memusuhi pemerintah jika tidak terjadi kesepakatan, hilangnya kontrol pembuatan keputusan, kemungkinan menjadi keputusan yang buruk jika kepentingan politik tidak bisa diabaikan, mengurangi dana implementasi atas proyek-proyek yang aktual.

Keuntungan atau kelemahan di atas tentu sangat bergantung pada keseriusan masyarakat dalam berpartisipasi. Hal ini bisa dikaitkan dengan derajat/ level partisipasi yang oleh Hobley dirumuskan menjadi beberapa tingkatan, yakni; a)Manipulatif Participation; b)Passive Participation; c)Participation by Consultation; d)Participation for Material Insentive; e)Functional Participation; f)Interactive Participation; dang)SelfMobilisation. Konsep lain adalah delapan anak tangga partisipasi masyarakat dari Arnstein (dalam Mitchell 1997) yang mengklasifikasi partisipasi masyarakat menjadi tiga derajat, yakni; Pertama, Derajat Tidak Ada Partisipasi: a]. Manipulasi dan b]. Terapi. Kedua, Derajat Semu: a]. Pemberian Informasi, b]. Konsultasi, dan c]. Penentraman. Dan yang ketiga, Derajat Kekuatan Masyarakat: a]. Kemitraan, b]. Kuasa yang didelegasi, dan c]. Kendali Warga. Terlepas dari uraian di atas, dalam sebuah konsep kebijakan atau perubahan kebijakan (policy change), partisipasi masyarakat secara umum dapat dilakukan dengan berbagai macam cara dan bentuknya. Namun sebelum ke arah itu, ada baiknya jika kita terlebih dahulu menelaah peran pemerintah daerah dalam rangka mendorong partisipasi masyarakat. Yang harus dilakukan adalah; a) Menyampaikan informasi tentang penyelenggaraan Pemerintah Daerah kepada masyarakat; b) Mendorong kelompok dan organisasi masyarakat untuk berperan aktif dalam penyelenggaraan Pemerintah Daerah melalui dukungan pengembangan kapasitas masyarakat; c) Mengembangkan kelembagaan dan mekanisme pengambilan keputusan yang memungkinkan kelompok dan organisasi kemasyarakatan dapat terlibat secara aktif (UU 23/2014 pasal 354 ayat 1). Sedangkan aspek partisipasi dimaksud mencakup: a) Penyusunan Perda dan kebijakan daerah yang 
mengatur dan membebani masyarakat; b) Perencanaan, penganggaran, pelaksanaan, pemonitoran, dan pengevaluasian pembangunan daerah; c) Pengelolaan aset dan/atau sumber daya alam daerah; dan d) Penyelenggaraan pelayanan publik.

Masih dalam pasal yang sama, namun pada ayat 3 lebih lanjut disebutkan bahwa bentuk partisipasi masyarakat dilakukan dalam bentuk konsultasi publik, musyawarah, kemitraan, penyampaian aspirasi, pengawasan, dan/atau keterlibatan lain sesuai dengan ketentuan peraturan peundang-undangan.

Dengan bahasa yang sedikit berbeda, Brinkerhoff dan Crosby (2002:64-70) mengistilahkan hal di atas dengan mekanisme partisipasi, diantaranya; a) Mekanisme Berbagi Informasi,yakni arus komunikasi searahagar selalu up date atas informasi, menjaga transparansi dan membangun legitimasi. Dari pemerintah dapat dilakukan melaui penyebaran dokumen resmi melalui surat kabar, majalah, radio, tv, hingga laman. Sebaliknya dari masyarakat dilakukan dalam wujud merespon setiap survey, kuesioner, akses telepon bebas pulsa, dan menyediakan beragam data, opini dan analisis. b) Mekanisme Konsultasi, merupakan komunikasi dua arah dan pertukaran pendapat yang melibatkan kegiatan berbagi informasi dan umpan balik serta reaksi. c) Mekanisme Kolaborasi merupakan gabungan kegiatan dimana inisiator mengundang kelompok lain untuk terlibat termasuk kalangan yang berwenang dan memiliki kontrol terhadappembuatan keputusan. d) Mekanisme Kerjasama Pembuatan Keputusan Bersama,berkenaan dengan pembagian kontrol atas pembuatan keputusan yang sangat berguna menyangkut pengetahuan eksternal aktor, kapasitas dan pengalaman. e) Mekanisme Pemberdayaan,memungkinkan pemangku kepentingan eksternal untuk mencapai tujuan mereka sendiri dengan memberikan ruang bagi inisiasi independen dan upaya untuk melakukan tindakan, meningkatkan kapasitas dan mendelegasikan wewenang pengambilan keputusan.

Yang lain adalah menurut Forum Inovasi (2002:5) bahwa partisipasi dapat berupa; mendiskusikan program atau rancangan kebijakan melalui public hearing, dialog interaktif; menyampaikan usulan/kebutuhan dalam berbagai kegiatan; menolak kebijakan dengan mendatangi kantor DPRD dan Pemerintah Daerah secara bersama-sama, merencanakan dan melaksanakan proyek oleh masyarakat. Sedangkan Bryant and White (1982:206) membedakan partisipasisecara horisontal, yakni bentuk partisipasi dimana orang-orang terlibat secara kolektif dalam upaya mempengaruhi kebijakan dan partisipasi vertikal adalah partisipasidimana anggota masyarakat mengembangkan hubungan tertentu dengan elit atau pejabat. Terakhir, menurut Oakley (dalam Dwiningrum, 2011:65-66) yang membedakan tingkatan partisipasi; 1) Manipulation, tingkat paling rendah mendekati situasi tidak ada partisipasi, cenderung berbentuk indoktrinasi. 2) Consultation, keadaan dimana stakeholder memiliki peluang untuk memberikan saran akan digunakan sebagaimana yang mereka harapkan. 3) Consensus Building, pada tingkat ini stakeholder berinteraksi untuk saling memahami dan dalam posisi saling 
bernegosiasi, toleransi dengan seluruh anggota kelompok. Kelemahan yang sering terjadi individu dalam kelompok cenderung pasif. 3) Decision Making, yakni adanya konsensus berdasar pada keputusan kolektif dan bersumber pada rasa tanggung jawab untuk menghasilkan sesuatu. Negosiasi pada tahap ini mencerminkan derajad perbedaan yang terjadi dalam individu maupuun kelompok. 4) Risk Taking, adalah proses yang berlangsung dan berkembang tidak hanya sekedar menghasilkan keputusan tetapi melahirkan akibat dari hasil yang menyangkut keuntungan, hambatan dan implikasi. Pada tahap ini semua orang memikirkan resiko yang diharapkan dari hasil keputusan. 5) Partnership, yaitu memerlukan kerja secara equal menuju hasil yang mutual. Equal tidak hanya sekedar dalam bentuk struktur dan fungsi tetapi dalam tanggung jawab. 6) Self Management, adalah puncak dari partisipasi masyarakat. Stakeholder berinteraksi dalam proses saling belajar (learning process) untuk mengoptimalkan hasil dan hal-hal yang menjadi perhatian.

Namun sebagaimana ditekankan oleh Brinkerhoff dan Crosby (2002:51) pada awal sub bab mengenai partisipasi masyarakat dalam proses kebijakan, bahwasanya partisipasi memerlukan tindakan orang dalam jumlah besar untuk mencapai hasil dan itu saja tidak cukup, melainkan tindakan orang dalam jumlah besar dimaksud harus terorganisir untuk memperluas pengaruhnya, untuk menekan pemerintah, dan untuk memperbesar tuntutannya. Terorganisir berarti, sebelum lebih jauh mengarah pada langkah-langkah yang akan ditempuh, strategi yang akan digunakan, mengerahkan tindakan-tindakan nyata, dan seterusnya, maka yang paling mendasar adalah pihak stakeholders dimaksud seyogyanya berada dalam naungan payung organisasi formal. Masih dalam referensi yang sama, stakeholder diartikan oleh Mitroff (1983) dan Freeman (1984) sebagai individu atau kelompok yang dapat berpengaruh atau dipengaruhi oleh pencapaian tujuan organisasi (dalam Brinkerhoff, 2002:59). Dalam referensi lain, stakeholder diartikan sebagai seseorang atau kelompok orang yang memiliki satu atau lebih kepentingan yang berbeda, dapat diartikan juga setiap orang atau kelompok orang yang dapat mempengaruhi atau dipengaruhi oleh tindakan, keputusan, kebijakan, praktik atau tujuan (Gunawan dan Pratama, 2008:47).

Lebih jauh dikatakan setidaknya ada tiga kriteria yang dapat digunakan untuk mengukur signivikansi stakeholder (Brinkerhoff, 2002:143), yakni; 1) jika aktor atau grup berada dalam posisi untuk melemahkan kewenangan atau dukungan politik terhadap pembuat keputusan atau organisasinya. 2) jika kelompok merepresentasikan dan atau mendukung terhadap perolehan keuntungan, menguatkan agen pelaksana kebijakan, mempertinggi kewenangan pembuat keputusan (dan kapasitasnya untuk mengamankan pemenuhan keputusan). 3) jika kelompok memiliki kemampuan mempengaruhi arah atau memadukan aktivitas organisasi pelaksana kebijakan. Dan mengingat sifat stakeholdersyang sangatluas, maka disini penekanannya hanyapada stakeholders Islam yang jika dikaitkan dengan tiga kriteria di atas telah mencakup semuanya, dengan 
catatan poin kedua yang berkenaan dengan keuntungan tidak diartikan sebagai materi, melainkan lebih mengarah pada keuntungan terpeliharanya masyarakat Kota Probolinggo dari kemerosotan dan kejahatan moral sebagaimana dikemukakan di atas.

\section{Metode Penelitian}

Penelitian yang dilaksanakan berjenis deskriptif kualitatif dengan maksud agar peneliti lebih mudah dalam penyajian data langsung dan memberikan gambaran se jelasjelasnya tentang partisipasi stakeholders Islam dalam reformasi Perda tentang usaha hiburan di Kota Probolinggo. Bogdan dan Taylor mendefinisikan penelitian ini sebagai prosedur penelitian yang menghasilkan data deskriptif berupa kata-kata tertulis atau lisan dari orang-orang dan perilaku yang dapat diamati(dalam Moleong, 2006:4).

Fokus penelitian dapat ditetapkan; 1) partisipasi stakeholders Islam yang berada di dalam ranah kebijakan, yakni perwakilan anggota dewan Kota Probolinggo yang tergabung dalam Fraksi atau Parpol berplatform Islam. 2) partisipasi stakeholders Islam yang berada di luar ranah kebijakan namun tergabung dalam organisasi formal sepertiperwakilan PC. NU, PC. Al-Irsyad, LDII, LDI, PD Muhammadiyah dan MUI Kota Probolinggo, termasuk pula HTI Kota Probolinggo yang pada saat itu belum dibubarkan. Dan, 3) partisipasi stakeholders Islam yang berada di luar ranah kebijakan namun tidak tergabung secara langsung dalam organisasi formal sebagaimana kriteri kedua namun sebagai basis massa pergerakan lanjutan bila dibutuhkan, yakni Kyai, pengurus, dan atau santri Ponpes di wilayah
Kota Probolinggo, tentunya dengan mengaitkan terhadap konsep partisipasi sebagaimana diulas di atas.

Lokasi yang di pilih adalah Kota Probolinggo mengingat peneliti berdomisili tidak jauh dari kota dimaksud, dan di kota inilah sedang hangat hingga saat ini kontrol masyarakat termasuk juga oleh stakeholders atas implementasi Perda tentang usaha hiburan yang telah disahkan. Sedangkan data primer dikumpulkan melalui teknik observasi dan wawancara mendalam dengan beberapa informan terkait dan data sekunder akan dikumpulkan dengan teknik dokumentasi termasuk dari media massa baik cetak maupun elektronik, AD/ART organisasi, peraturan perundangan, Perda, Perwali, dan sebagainya. Adapun metode analisis data yang digunakan adalah model analisis interaktif dari Miles dan Huberman (dalam Sugiyono, 2008:91) yang langkah-langkahnya meliputi; reduksi data, penyajian data dan verifikasi atau penarikan kesimpulan.

\section{HASIL DAN PEMBAHASAN}

Sebagaimana telah diurai di atas, bahwasanya tulisan ini akan dibagi ke dalam tiga fokus, maka fokus pertama, yakni stakeholders Islam di dalam ranah kebijakan.Tidak dapat dipungkiri bahwasastakeholderini merupakan bagian yang paling berwenang untuk melakukanperubahan kebijakan (policy change), karena salah satu fungsinya adalah legislasi yang berkenaan dengan pembuatan kebijakan.Dalam konteks ini Rasyid (2001:222) menilai perlunya penguatan peran DPRD yangdalam proses legislasi ini dilakukan melalui pembentukan Perda bersama kepala 
daerah. Maka upaya konkrit yang dilakukan oleh DPRD Kota Probolinggoadalah mengusulkan Rancangan Perda melalui Badan Legislasi (Banleg) dengan menggandeng Lembaga Pengabdian dan Pengembangan Masyarakat (LPPM) UB terkait penyusunan naskah akademiknya. Terpilihnya UB sebagai tim pakar ini menyisihkan beberapa nama besar perguruan tinggi lain, seperti Unej dan UIN Sunan Ampel. Disamping itu dilakukan pula dialog untuk menjaring masukan atau aspirasi dari stakeholders secara keseluruhan, seperti penyedia hiburan malam/pelaku usaha, masyarakat, NU, Muhammadiyah, organisasi kepemudaan, hingga perwakilan penikmat kebijakan (beneficieris) dan perwakilan wartawan. Fungsi legislasi ini di masa kekinian banyak mendapat sorotan,baik dalam kontekstingkat produktivitasnya maupun menyangkut kualitas dari produk legislasi yang dihasilkan, termasuk kaitannya dalam pelibatan partisipasi masyarakat pada proses penyusunan dan perancangan suatu Peraturan Daerah (Halim,2009).

Sebagai tambahan, pada saat itu, Raperda ini juga dimasukkan ke dalam Prolegda atau Program Legislasi Daerah. Perbedaan teknis sempat mengemuka dalam agenda pandangan fraksi-fraksi terhadap pandangan Walikota atas Rancangan Perda yang diinisiasi. Walikota mengusulkan dihapusnya diskotik dalam usulan tersebut, namun Fraksi PKB dan Nasdem pada saat itu mengemukakan ketidaksetujuannya atas penghapusan diskotik, yang menurut mereka sejatinya harus diatur tersendiri dan dilarang, bukan di hapus. Karena jika di hapus justru akan menjadi celah bagi pengusaha untuk mengajukan ijin.

Walau demikian, hembusan angin berbeda di tengah-tengah jalan juga mengemuka dalam hal ini, yakni usulan pembatalan Raperda dengan opsi revisi atas Perda Kota Probolinggo 9/2010 yang disampaikan oleh Wakil Banleg DPRD Kota Probolinggo sendiri.Namun, akhirnya anggota dewan yang terhormat bersepakat memilih untuk menggantinya dengan yang baru. Dalam pandangan mereka, jika hanya revisi hasilnya tidak akan maksimal dan tetap tidak akan menghilangkan kemandulan pemerintah dihadapan pengusaha. Walaupun jika dirunut lebih jauh, kemandulan juga dikarenakan Perda dimaksud tidak memiliki Perwali sebagai acuan teknis lebih lanjut. Memang, ada beberapa Perda yang tidak membutuhkan Perwali. Namun dalam konteks ini, Perda dimaksud memiliki sifat mengatur sehingga memang membutuhkan Perwali. Terlebih dalam beberapa pasal diantaranya secara jelas tersurat membutuhkan Perwali sehingga ketika dihadapkan pada kasuistik tertentu, seperti penyalahgunaan ijin maka pemerintah tidak serta merta dapat melakukan penutupan karena didalamnya masih tercakup ijin karaoke, resto dan cafe yang menjadi satu sesatuan. Padahal yang disinyalir melanggar hanyalah karaokenya saja. Jika dipaksakan untuk mengambil tindakan penutupan maka dikhawatirkan pemerintah akan dituntut di PTUN, dan kalah. Inilah penyebab kemandulan tersebut. Atas fenomena demikian, berdasar data sekunder yang penulis peroleh per tahun 2015 silam setidaknya ada 29 Perda Kota Probolinggo 
yang tidak memiliki Perwali dengan variasi keluaran mulai Perda tahun 2005 hingga tahun 2014, termasuk Perda 9/2010 (Radar Bromo, 18 Februari 2015).

Dalam konsep kebijakan, kebijakan ataupun perubahan kebijakan tentu tidak akan dengan sendirinya terbentuk melainkan ada hal yang melatarbelakangi, entah itu bersifat penyesuaian dengan perubahan jaman, adanya suatu tuntutan, fenomena yang berkembang pasca dikeluarkannya kebijakan dimaksud, desakan pelaku usaha (investor), hingga tuntutan stakeholders-Islamsebagaimana yang terjadi dalam kasuistik ini. Disadari ataupun tidak, ada banyak sekali stakeholders dalam suatu kebijakan,namun harus pula diakui jika dalam hal ini hanyalah sekelumit stakeholder Islam saja yang banyak mengemuka, itupun jika dikerucutkan lagi hanya mengarah pada mereka yang berlabelkan NU. Ini merupakan bukti nyata bahwasanya kalangan Nahdliyin sangat peduli terhadap keadaan daerah yang dipiijak termasuk diantaranya pengambilan sikap atas kebijakan yang membawa kepada kemudharatan. Maka berkenaan dengan hal ini akumulasi dari semua fenomena yang diakibatkan oleh lahirnya suatu kebijakan tertentu berikut aktualisasi implementasinya di lapangan kemudian melahirkan sebuah perubahan kebijakan. Tentunya dengan tekanan stakeholders yang mengitarinya. Sebagai contoh, pengeluaran ijin salah satu tempat karaoke yang dinilai tidak sesuai RTRW, adanya pelanggaran ijin usaha, terjadinya keributan, semakin terasanya kemerosotan moral, dan sebagainya, kesemuanya kemudian melahirkan embrio perubahan kebijakan.
Sikap stakeholders Islam yang berada di dalam gelanggang kebijakan ini, yakni Fraksi PKB dan PPP kemudian tidak tinggal diam. Atas mencuatnya kasus tarian beraura mesum misalnya, maka disikapi bersama-sama dengan anggota dewan daerah yang lain, utamanya di Komisi $X$ dengan menggelar hearing yang dilakukan dengan pihak-pihak terkait, seperti Majelis Ulama Indonesia (MUI), Kementerian Agama, Badan Penanaman Modal dan Pelayanan Perizinan, Bappeda, Dinas Pendidikan Kota Probolinggo, PCNU, Dewan Pendidikan dan tokoh masyarakat di tataran Kota Probolinggo. Tidak hanya itu, pengeluaran surat rekomendasi Nomor: 170/280/425,050/2015 kepada Walikota untuk mencabut ijin tempat hiburan malam juga pernah dilayangkan. Fenomena lain terjadi ketika Komisi A mengetahui jika pendapatan pajak dari sektor hiburan malam ternyata jauh lebih kecil dari biaya operasional dalam upaya pengawasan dan penertibannya. Dikatakan bahwa pendapatan yang diraih pada saat itu tidak lebih dari 168 juta rupiah per tahun. Maka, hal ini dipandang sangat kecil mengingat faktor kemerosotan moral generasi bangsa yang tak ternilai dengan uang. Atas fenomena ini kemudian secara tegas Komisi A merekomendasikan tempat hiburan malam di Kota Probolinggo seluruhnya ditutup. Dinamika yang lain sebagai akumulasi atas fenomena kebijakan juga terjadi ketika pemerintah atau Walikota bersikap inkonsisten, dari yang semula hendak menutup JJ. Royal kemudian berubah hanya memberi peringatan keras. Maka hal ini kemudian kembali melahirkan gelaran hearing. Inilah sejatinya bahwa DPRD Kota 
Probolinggo telah melakukan fungsi pengawasan terhadap pelaksanaan Perda, disamping melakukan fungsi legislasi di atas. Ini merupakan pengawasan politik yang tentunya mewakili komunitas yang ada di dalam masyarakat, karena DPRD merupakan representatif dari masyarakat. Maka dalam fungsi ini DPRD juga memainkan peranannya sebagai public services watch (Usaid, 2007:36).

Pendek kata, ending-nya kemudian mengerucut pada langkah pengusulan Rancangan Perda tentang hiburan yang ditanggapi oleh pemerintah.Setelah melalui proses yang panjang dan berliku, seperti dimasukkannya pasal yang membedakan secara tegas atas karaoke dewasa dan karaoke keluarga, pintu yang terbuat dari kaca bening, lampu ruangan tersentral yang tidak bisa dimatikan seenaknya oleh pengunjung, menjaga pekerja dan pengunjung untuk berpakaian rapi dan sopan sesuai kearifan lokal, tidak ada fasilitas kamar mandi di dalam setiap ruang karaoke, jarak tempat hiburan harus satu kilometer dari tempat ibadah dan lembaga pendidikan -walaupun kemudian yang terealisir hanya 300 meter.Hal ini dikarenakan dalam setiap tahapannya selalu menggunakan mekanisme voting sehingga kelompok yang lemah susah untuk diakomodir secara maksimal. Namun, semuanya kemudian melahirkan kebijakan baru, yakni Perda Nomor 9 Tahun 2015 menggantikan Perda lama, yakni Nomor 9 Tahun 2010.

Selanjutnya adalah Fokus yang kedua, yaknipartisipasi stakeholders Islam di luar ranah kebijakan namun tergabung dalam organisasi formal.Berdasar pada pendapat Muluk (2007) bahwa pihak-pihak yang terlibat dalam pelaksanaan partisipasi masyarakat yang paling utama adalah masyarakat itu sendiri, maka dalam hal ini penulis hendak menekankan pandangan selanjutnya, bahwa masyarakat dimaksud haruslah terorganisir baik langkahnya, strateginya, tindakan nyatanya, dan yang lainnya, terlebih dasar lagi adalah adanya wadah organisasi formal yang melingkupinya (Brinkerhoff dan Crosby (2002:51). Maka, dalam sub bahasan inilah jawabannya. Harus diakui jika hendak melihat bagaimana partisipasi mereka dalam tahap perumusan dengan pandangan duduk satu forum bersama legislatif dan eksekutif memanglah minim. Namun jika hendak melihat proses dan kedewasaan masyarakat dalam mengawal kebijakan, termasuk berubahnya kebijakan maka disinilah gambarannya. Bahwasemua usaha yang telah dicapai di atas berembrio dari stakeholders golongan ini, yakni stakeholders yang benafaskan keIslaman. Fenomena banyaknya mudharat dan kemerosotan moral yang terjadi di Kota Probolinggo sebagai akibat dari menjamurnya hiburan malam dianggap sebagai ladang untuk ber amar ma'ruf nahi mungkar. Tidak dapat dipungkiri jika tujuan utama mereka pada awalnya adalah untuk menutup seluruh tempat hiburan malam di Kota Probolinggo, namun karena di rasa terlalu berat, mengingat Kota Probolinggo sebagai kota transit berikut segenap lapisan masyarakatnya juga membutuhkan hiburan, walaupun tidak seperti yang diharap pada saat itu, maka upaya tersebut diurungkan. Namun demikian, gelora untuk mewujudkan Kota Probolinggo yang lebih bermartabat, beriman dan jauh dari kemaksiatan tetap menjadi agenda kontinuum, utamanya dalam 
mengawal pelaksanaan Perda hiburan malam oleh pemerintah.

Berdasar pada itulah kemudian stakeholders yang sebagian besarnya berada dalam payung Nahdlatul Ulama, khususnya PCNU ini melancarkan segenap aksinya secara maksimal. Hal ini tergambar mulai dari pernyataan sikap yang bersifat menekan melalui dilayangkannya Surat bernomor: 018/PC/A.II/L-38/III/2013 yang ditujukan langsung kepada Walikota Probolinggo tatkala ada protes warga terkait ketidaksetujuannya terhadap berdirinya salah satu tempat karaoke yang dinilai tidak tepat. Surat dimaksud bertujuan agar pemerintah meneliti, mengkaji dan meninjau kembali ijin terhadap salah satu tempat hiburan malam, memperhatikan AMDAL dan RTRW dalam setiap kebijakan yang dibuat, disamping menjunjung tinggi moral, etika, nilai dan norma serta kemaslahatan umum. Dalam perkembangannya kemudian melalui surat lain yang bernomor: 123/PC/A.II/L38/IX/2014, PCNU mendesak pemerintah untuk menutupnya, yakni tempat hiburan malam Ayang yang terletak di jalan Mastrib.

Beriring dengan dinamika dunia hiburan malam, maka ketika ada fenomena tak sedap berhembus, seketika pula stakeholderini mengambil sikap. Salah satunya adalah pasca dilakukan penggrebekan sexy dancer di JJ Royal maka upaya lain yang dilakukan adalah mengutuk keras kejadian tersebut melalui tulisan dengan menggandeng media cetak lokal, yakni Radar Bromo.Tidak hanya dalam setiap terjadinya fenomena yang secara langsung berhubungan dengan implementasi Perda dimaksud, seperti adanya keributan pengunjung, protes warga, dan atau penggrebekan yang mendapati pengunjung dan pemandu lagu setengah telanjang di dalam ruang karaoke atau terkuaknya tarian seksi, dan sebagainya. Bukti keseriusan lain diperlihatkan oleh stakeholder ini dalam gelaran Muskercab II PCNU Kota Probolinggo yang sekali lagi menghasilkan rekomendasi kepada Walikota dan DPRD Kota Probolinggo untuk menutup tempat hiburan malam di Kota Probolinggo, tidak menerbitkan perijinan sejenis yang baru, menindak tegas para pelanggarnya, mengarahkan investor baru tidak pada hiburan malam melalui surat resmi. Disamping itu untuk memperkuat taji dalam mempengaruhi kebijakan, kelompok ini juga berkoordinasi dengan PWNU Jawa Timur, dan setiap langkahnya pula senantiasa dilaporkan ke PPNU. Hasilnya, PWNU kemudian melayangkan surat kepada pemerintah bernomor: 794/PW/A1/L/IV/2015 untuk mencabut ijin hiburan malam yang terbukti melanggar. Namun, ketika inkonsistensi sikap pemerintah terjadi sebagaimana revisi penutupan JJ Royal menjadi hanya sebatas peringatan keras, hal lain yang dilakukan adalah merapatkan barisan kepada Kapolresta yang dinilai lebih tegas dalam bersikap.

Di sisi lain, beberapa upaya stakeholders lain dalam mempengaruhi kebijakan ini datang dari Jaringan Komunikasi Madrasah Aliyah Swasta (Jakmas) yang menemui DPRD Kota Probolinggo untuk meminta agar dewan yang terhormat mengawal Perda hiburan malam dan peredaran miras. Pernyataan sikap juga dilontarkan oleh Forum Komunikasi Ormas Islam Kota Probolinggo yang intinya mendesak pemerintah mencabut ijin operasional JJ Royal, tidak menerbitkan ijin 
baru terhadap usaha karaoke, melakukan pengawasan berkelanjutan dan menindak tegas kepada pelanggar Perda melalui instansi yang berwenang. Stakeholder lain ada MUI Kota Probolinggo yang bahkan telah mengeluarkan fatwa tentang pornografi dan pornoaksi jauh sebelum desas desus kasus ini mencuat. Ada pula wujud partisipasi yang berbeda dari pihak PMII Kota Probolinggo, yaknidengan menggelar aksi turun ke jalan sebagai tindak lanjut atas surat PCNU dan PWNU yang dinilai tidak direspon oleh pemerintah.

Lebih jauh berkenaan dengan pembahasan Rancangan Perda yang baru, sebagai stakeholder kebijakan daerah yang sangat pro aktif, partisipasi kelompok ini diwujudkan dalam keikutsertaannya dalam proses hearing atau rapat dengar pendapat bersama DPRD dan Pemerintah Kota Probolinggo. Beberapa pasal krusial sebagaimana disebut di atas telah lahir berkat upaya gigih stakeholders ini. Walaupun salah satu informan yang berhasil penulis temui juga merasa heran, mengapa jarak lokasi hiburan yang diperjuangkan satu kilometer tidak boleh berdekatan dengan tempat ibadah dan sarana pendidikan pada akhirnya terealisir hanya sejauh tiga ratus meter. Beliau mengungkap bahwasanya inilah bukti kekuatan investor dihadapan penggagas kebijakan. Dengan kata lain untuk tidak mengatakan bahwa mereka telah "dibeli". Fenomena demikian oleh Wahab (1998:51-53) dikatakan muncul akibat proses kebijakan selalu didominasi oleh penguasa ditingkat elit saja. Bahkan Parsons (1997) menyebut hal ini sebagai fenomena iron cage, yaitu struktur birokrasi yang tertutup dan tidak mempedulikan dinamika yang ada diluar. Atau dalam istilah lain disebut sebagai fenomena iron triangle (Grant, 1998).

Terungkap pula bahwasanya tidak dalam setiap tahapan mereka dilibatkan sampai akhirnya Perda baru disahkan. Namun demikian, Perda yang baru di rasa memiliki banyak kemajuan dibanding yang lama. Dan mereka juga berjanji untuk senantiasa mengawalnya.Ini berarti sudah ada akomodasi kepentingan mereka atas Perda yang baru. Hal demikian selain merupakan modal sosial yang harus senantiasa dipelihara (Uphoff, 1998)pada akhirnya akan membawa mereka untuk semakin terbiasa dengan proses kebijakan, ini berartiterjadi pemupukan kedewasaan pengalaman berpartisipasi yang akan bermuara pada suksesnya dalam mengamankan setiap proses kebijakan dan mempengaruhi kebijakan (dalam Brinkerhoff dan Crosby, 2002:76).

Kedewasaan para stakeholderIslam ini dalam berpartisipasi jika dikaitkan dengan konsep partisipasi yang dikemukakan oleh Hobley sudah masuk pada taraf SelfMobilisation atau taraf yang paling tinggi, yakni partisipasi yang dilakukan atas pengambilan inisiatif secara independen dari lembaga luar untuk perubahan sistem. Masyarakat mengembangkan hubungan dengan lembaga eksternal dan tetap mengawasinya. Jika penulis kaitkan pula dengan konsep delapan anak tangga partisipasi masyarakat dari Arnstein (1971) maka partisipasi stakeholder Islam ini sudah masuk pada level yang tertinggi juga, yakni Kekuatan Masyarakat (Degrees of Citizen Powers)dimana didalamnya berisikan tiga anak tangga, yakni kemitraan, kuasa yang 
didelegasi, dan kendali warga. Walaupun tidak semuanya berada dalam taraf yang sempurna.Namun menurut hemat penulis hal itu bukanlah murni karena keinginan mereka melainkan sistem dan budaya pemerintahan setempat yang masih setengah hati untuk melibatkannya secara penuh. Namun demikian, peran pemerintahdaerah dalam rangka mendorong partisipasi masyarakatsebagaimana semangat ruh UU 23/2014 pasal 354ayat 1 patut diapresiasi dan bila perlu dikembangkan agar partisipasi masyarakat dan stakeholders secara umum dapat ter-cover dalam tahapan kebijakan yang lebih luas.Bagaimanapun perjuangan masih tetap berlanjut. Bahkan pasca perubahan perda yang baru, dimana PCNU dan PD Muhammdiyah tetap mengawal implementasi Perda dimaksuddan akan senantiasa bersikap kritis baik melalui surat, audiensi, bahkan jika tidak dilaksanakan dengan baik mereka tidak akan mencegah jika kelak masyarakat yang lebih besar melakukan protes dengan jalan berdemonstrasi.

Fokus yang terakhir adalah partisipasi stakeholders Islam yang berada di luar ranah kebijakan dan tidak tergabung secara langsung dalam organisasi formal.Untuk golongan ini, tidak banyak data yang dapat penulis gali, karena sejatinya stakeholderini hanya dipersiapkan jika memang upayaupaya yang dilakukan tidak membuahkan hasil. Bentuknya adalah turun ke jalan atau berdemonstrasi dengan catatan tidak membawa atribut yang disandang, seperti nama pondok pesantren, kyai, label NU, Muhammadiyah dan atau kelompok Ormas Islam yang lain. Namun demikian keberadaannya tetap tidak bisa dipandang sebelah mata, hanya saja merupakan jalan paling akhir untuk ditempuh. Walaupun pada gambaran di atas sudah terkuak adanya kelompok yang turun ke jalan, berdemonstrasi, mengutarakan tuntutannya, yakni perwakilan stakeholder Islam; PMII. Namun sayangnya tidak dibarengi dengan aksi kelompok ini sehingga pengerahan massa tidak bisa kita potret secara maksimal, berikut reaksi yang dihasilkan.

Bagaimana pun, aksi demo pada dasarnya merupakan wujud aplikasi dari nilai pancasila sila ke 4 walaupun dengan wujud yang lain dan merupakan ciri dari adanya sebuah negara yang dikatakan demokratis. Artinya, demonstrasi merupakan bentuk penyampaian aspirasi legal untuk dilakukan oleh berbagai elemen mayarakat. Dikatakan olehSiregar (1994:26), demonstrasi merupakan bentuk ekspresi yang produktif dari sekelompok orang yang berisikan tuntutan atas keadaan, kenyataan, luapan kesadaran dan bahkan merupakan bentuk pendidikan kritis kebangsaan. Karenanya menurut hemat penulis tidak ada yang salah ketika stakeholder Islam yang memang kaya akan massa ini memeliharanya sebagai amunisi terakhir.

\section{PENUTUP}

\section{Kesimpulan}

Atas penelitian yang telah dilakukan maka dapat ditarik kesimpulan bahwa:

a. Partisiapasi stakeholders Islam di dalam ranah kebijakan dilakukan oleh Fraksi PKB dan PPP yang kemudian bersamasama dengan anggota dewan lain yang tergabung Komisi $\mathrm{X}$ menjalankan kewenangannya.Kewenangan legislasi dilakukan melalui usulan Rancangan 
Perda dan memasukkannya ke dalam Prolegda dengan menggandeng LPPMUB dan melakukan hearing bersama segenap stakeholder yang ada.Kewenangan pengawasan dilaksanakan terhadap Perda berikut implementasinya yang dalam suatu momen kerap memberikan rekomendasi kepada pemerintah, dan sebagainya.

b. Partisipasi stakeholders Islam di luar ranah kebijakan yang tergabung dalam organisasi formal merupakan embrio berubahnya Perda tentang hiburan malam di Kota Probolinggo, utamanya dari kalangan yang berlabelkan NU, walaupun di sisi lain ada pula PD Muhammadiyah, PC. Al-Irsyad, LDII, LDI, MUI, dan lainlain. Partisipasi kelompok ini secara pro aktif mengawal setiap fenomena yang terjadi sebagai akibat dari diberlakukannya Perda dimaksud, mulai dari media surat rekomendasi, heraing, pembahasan dalam Muskercab PCNU, memberikan dukungan moral kepada penegak hukum, dan sebagainya.

c. Sedangkan partisipasi stakeholders Islam yang berada di luar ranah kebijakan dan tidak tergabung secara langsung dalam organisasi formaldigunakan sebagai amunisi terakhir melalui media demonstrasi.

\section{Rekomendasi}

a. Pelibatan lebih banyak lagi partisipasi masyarakat dan stakeholder dalam setiap tahapan kebijakan daerah.

b. Dewan yang terhormat hendaknya tidak selalu menggunakan media voting dalam mengambil keputusan. Pengutamaan musyawarah mufakat akan lebih mengakomodir semua kepentingan, termasuk yang lemah secara kuantitas.

c. Dalam rangka merancang naskah akademik Perda hendaknya juga menggandeng akademisi lokal yang diambil dari Perguruan Tinggi di lingkup Probolinggo.

d. Segera munculkan Perwali atas Perda 9/2015 sebagai acuan teknis suatu, secara umum juga terhadap Perda lain yang bersifat mengatur.

e. Pemerintah hendaknya lebih peka terhadap dinamika dan tuntutan masyarakat yang berkembang agar tidak menimbulkan gejolak yang lebih besar.

f. Masyarakat seacara luas hendakanya lebih perduli terhadap segala sesuatu yang berkenaan dengan Perda, sebagaimana telah dicontohkan oleh stakeholdersIslam, serta tidak bergerak secara parsial melainkan bergabung dalam organisasi formal baik baru ataupun bergabung ke dalam Ormas yang sudah ada.

\section{DAFTAR PUSTAKA}

Brinkerhoff, Derick W., and Benjamin L. Crosby. 2002. Managing Policy Reform; Concept and Tools for Decision-Makers in Developing and Transitioning Country.USA, Bloomfield: Kumarian Press.

Dwiningrum, Siti Irine Astuti. 2011. Desentralisasi dan Partisipasi Masyarakat dalam Pendidikan. Yogyakarta: Pustaka Pelajar.

Gunawan, W., dan Pratama Yeremia Adi. 2008. Risiko Hukum dan Bisnis 
Perusahaan tanpa CSR. Jakarta: Niaga Swadaya.

Halim,Hamzah. 2009. Cara Praktis Menyusun \& Merancang Peraturan Daerah (Suatu Kajian Teoritis \& Praktis disertai Manual). Jakarta:Kencana Prenada Media Group.

Hardjasoemantri. 2003. Good Governance dalam Pembangunan Berkelanjutan di Indonesia. Makalah untuk Lokakarya Pembangunan Hukum Nasional ke VIII di Bali.

Irvin, Renee A., and John Stansbury, CitizenParticipation in Decision Making: Is It Worth the Effort? Public Administration Review; Jan/Feb. 2004; 64, 1; ABI/INFORM Global.

Jawa Pos. Radar Bromo. 26 Maret 2013.

2 Feberuari 2015. 18 Februari 2015. 5 Mei 2015

Jordan, Grant. 1998.Indirrect Causes and Effect in Policy Change: The Brent Spar Case, Public Administration, Vol. 76 Winter.

Muluk, K. 2007. Menggugat Partisipasi Publik dalam Pemerintahan Daerah. Malang: LPD FIA UB dan Bayu Media.

Mitchell, Bruce. 1997. Resources and Environmental Management.First Edition. Addison Wesley Longman Limited.

Moleong, J. L.2006. Metodologi Penelitian Kualitatif,Bandung: Remaja Rosdakarya.

Parsons, Wayne. 1997. Public Policy: An Introduction to The Theory and Practice of Policy Analysis, Edwadr Elgar Publishing.
Peraturan Daerah Kota Probolinggo Nomor 2 Tahun 2010 tentang Rencana Tata Ruang Wilayah (RTRW).

- Nomor 9 Tahun 2010 tentang Ijin Hiburan.

. Nomor 9 Tahun 2015 tentang Penataan, Pengawasan, dan Pengendalian Usaha Tempat Hiburan.

Ruslan, D. 2005. Tata Pemerintahan yang baik (Good Governance) dan Pembangunan Daerah. Jurnal Kewarganegaraan.

Undang-Undang Nomor 23 Tahun 2014 tentang Pemerintah Daerah.

Wahab, Solichin Abdul. 1998. Analisis Kebijakan Publik Teori dan Aplikasinya. Malang: Fakultas Ilmu Administrasi Universitas Brawijaya.

Siregar,Hariman. 1994. Hati Nurani Seorang Demosntran. Jakarta: Mantika Media Utama.

Sumanto, Hetidijah Sj. 2006. Inovasi, Partisipasi dan Good Governance. Jakarta: Yayasan Obor Indonesia.

Usaid, 2007. Membina Hubungan dengan Konstituen. Jakarta: LGSP,

Laman:

www.wartabromo.com 